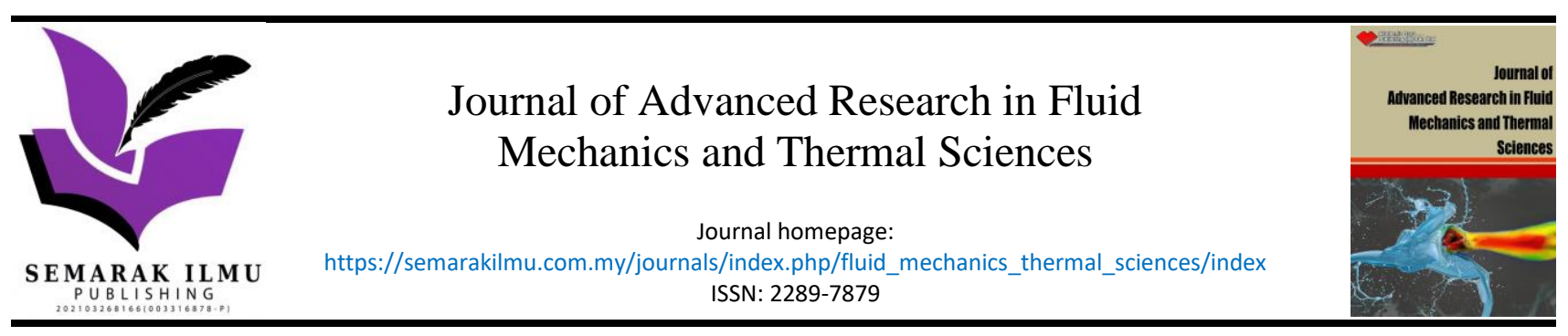

\title{
Improvement of Biocoal Quality from Empty Oil Palm Fruit Bunches by Using Peat Water to Reducing Potassium Content and Torrefaction at $300^{\circ} \mathrm{C}$ to Increasing Heating Value
}

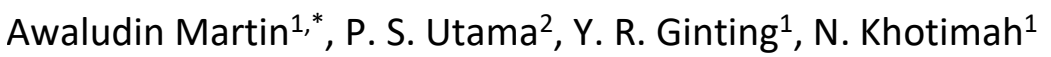 \\ Laboratory of Energy Conversion, Department of Mechanical Engineering, Faculty of Engineering, University of Riau, Indonesia \\ Department of Chemical Engineering, Faculty of Engineering, University of Riau, Indonesia
}

\section{ARTICLE INFO}

\section{Article history:}

Received 26 September 2021

Received in revised form 9 November 2021

Accepted 15 November 2021

Available online 29 December 2021

\section{Keywords:}

Oil Palm Empty Fruit Bunches; Biocoal; Heating Value; Potassium Oxide

\section{ABSTRACT}

Consumption of fossil energy continues to increase and therefore fossil energy reserves are decreasing, thus the switchover of using fossil energy into new and renewable energy is necessary. Biomass especially from oil palm empty fruit bunches is one of potential resource as new and renewable energy that can mixture with coal as fuel for power plant. However, biomass from oil palm empty fruit bunches has several weaknesses as fuel; it is containing of high potassium content and low heating value. Potassium content will react with oxygen and resulting potassium oxide $\left(\mathrm{K}_{2} \mathrm{O}\right)$ in the furnace of boiler and it can cause the fouling and slagging at the tubes and walls of boiler. Washing with flowing peat water is one of method that used to reduce potassium content in empty oil palm fruit bunches and torrefaction at $300 \mathrm{C}$ is a method is use to increase the heating value of biomass from empty oil palm fruit bunches. This research resulted the potassium, potassium oxide content is $5 \%$ and $3.7 \%$ respectively by flowing peat water at $5 \mathrm{lpm}$ for 60 minutes, and the heating value of biomass by torrefaction process at $300 \mathrm{C}$ for 30 minute was obtain at $28742.17 \mathrm{~kJ} / \mathrm{kg}$.

\section{Introduction}

Currently, the consumption of fossil energy continues to increase and therefore fossil energy reserves are decreasing, thus the switchover of using fossil energy into new and renewable energy is necessary. The switchover of energy fossil to new and renewable energy is necessary to maintain energy availability in the future [1]. Renewable energy such as geothermal, solar, wind, hydro and biomass are energy that comes from nature that can renew, where its utilization of renewable energy is divide into energy that has been develop but is limited, and that has been develop but is still at the research stage [2].

New energy such as hydrogen, coal bed methane and biocoal is an energy that were produce by new technology and has not been use in general, where that energy is comes from renewable or non-

\footnotetext{
* Corresponding author.

E-mail address: awaludinmartin01@gmail.com
}

https://doi.org/10.37934/arfmts.90.2.3241 
renewable energy. This energy is also often referred to as alternative energy in the hope that in the future it will reduce conventional energy that has been used $[3,4,6]$.

The projection of primary energy supply in 2050 originating from new and renewable energy is $31.2 \%$ and $12.3 \%$ of which is sourced from biomass, this increases quite significantly where in 2020 the supply of primary energy from new and renewable energy is only 13, 44\% [5]. Table 1 show the Indonesia's primary energy supply.

Table 1

Indonesia's Primary Energy Supply 2015-2050 [5]

\begin{tabular}{|c|c|c|c|c|c|c|c|c|c|c|c|}
\hline \multirow[t]{2}{*}{ No. } & \multirow[t]{2}{*}{ Type of Energy } & \multicolumn{10}{|c|}{ Million Tonnes Oil Equivalent (MTOE) } \\
\hline & & 2015 & 2016 & 2017 & 2018 & 2019 & 2020 & 2025 & 2030 & 2040 & 2050 \\
\hline 1 & Crude oil & 75.7 & 76.4 & 77.7 & 79.3 & 81.4 & 82.8 & 98.7 & 112.9 & 150.9 & 197.7 \\
\hline 2 & Natural gas & 43 & 45.9 & 49.4 & 53.1 & 56.5 & 61 & 89.5 & 109.1 & 171.6 & 242.9 \\
\hline 3 & Coal & 67.6 & 73.5 & 80.7 & 88.4 & 97.6 & 104.8 & 119.8 & 147.5 & 198.4 & 255.9 \\
\hline 4 & Geothermal & 2.6 & 3.5 & 4.4 & 5.5 & 6.8 & 8.9 & 21.8 & 28 & 42.7 & 58.8 \\
\hline 5 & Water & 6.9 & 6.9 & 7 & 7.3 & 7.5 & 7.8 & 24.9 & 29.3 & 39.7 & 55.3 \\
\hline 6 & Micro hydro & 0.3 & 0.3 & 0.5 & 0.8 & 1.1 & 1.6 & 5.2 & 6.2 & 8 & 10.2 \\
\hline 7 & Biomass & 10.4 & 11.9 & 13.3 & 15 & 16.8 & 19.1 & 33.8 & 49.8 & 83 & 124.2 \\
\hline 8 & Solar & 0.1 & 0.1 & 0.2 & 0.3 & 05 & 0.7 & 4.3 & 9.1 & 18.5 & 29.6 \\
\hline 9 & Wind & 0 & 0 & 0.1 & 0.2 & 03 & 0.5 & 1.8 & 6.7 & 16.4 & 27.6 \\
\hline 10 & $\begin{array}{l}\text { Other } \\
\text { renewable } \\
\text { energy }\end{array}$ & 0 & 0 & 0 & 0 & 0 & 0 & 0.5 & 1.3 & 4.3 & 9.9 \\
\hline Total & & 206.6 & 218.5 & 233.3 & 249.9 & 268.5 & 287.2 & 400.3 & 499.9 & 733.5 & 1012.1 \\
\hline
\end{tabular}

To achieve the energy distribution target, Ministry of Energy and Mineral Resources continues to increase the use of new and renewable energy is through the co-firing method at power plants steam by utilizing biomass as a coal mixture [6]. The potential of biomass in Indonesia that can used as an energy source is very abundant, especially waste originating from plants that have the potential to be developed. Usually, the biomass that use for source of energy is biomass, which has low economic value or is a waste after the primary product is take [7].

Oil palm empty fruit bunches is one of the largest sources of biomass where the oil palm area in Indonesia was increase every year. The area of oil palm plantations in Indonesia is around 14.32 million hectares where the large plantations is 8.51 million hectares with oil palm production of 26.57 million tons and the people's oil palm plantation area of 5.81 million hectares with a production of 13.99 million tons. Riau is the province with the largest oil palm plantation area in Indonesia is about 2.74 million hectares in 2018 [8]. Every 1 hectare of oil palm plantations will produce about 1.5 tons of empty oil palm bunches [9]. The large amount of availability of empty oil palm fruit bunches as biomass so it is very suitable if this biomass is converted into biocoal.

Utilization of biomass as a fuel is limited by its characteristics such as low bulk density, high moisture content, inconsistent particle size, heterogeneous chemical composition, hydrophilicity, fibrous nature and relatively low calorific value. One of the conversion technologies that can be applied to improve the properties of biomass is torrefaction. The torrefaction of biomass will change its physical and thermal properties [10].

Biocoal from biomass is produced by processing dry biomass in an inert environment (without oxygen) at high temperatures and the conversion of biomass into biocoal is depend on the characteristics of the source material [11]. Torrefaction is typically performed in an inert environment with mild $\left(200-250^{\circ} \mathrm{C}\right)$ or severe $\left(250-300^{\circ} \mathrm{C}\right)$ torrefaction conditions. In addition, sufficiently high amount of energy obtained from severe reaction has been reported to be suitable for energy production sector. Based on the advantages as mentioned above, solid products obtained from 
torrefaction have potential to be used as coal replacement [12]. Torrefaction treatment on many species showed significant improvement of the biomass quality such as low volatile matters, high carbon content and importantly high calorific value and emit less carbon monoxide gas which is very good for thermal energy conversion process. [13].

However, biomass from oil palm empty fruit bunches has several weaknesses as fuel; it is contained of high potassium content and low heating value. Potassium content will react with oxygen and resulting potassium oxide $\left(\mathrm{K}_{2} \mathrm{O}\right)$ in the furnace of boiler and it can cause the fouling and slagging at the tubes and walls of boiler [14].

The aim of this research is to increasing the heating value of biocoal through a torrefaction process and a washing process with flowing peat water to reduce potassium content.

\section{Methodology}

\subsection{Material}

\subsubsection{Oil palm empty bunches}

The materials used in this analysis are empty fruit bunch (EFB) as shown in Figure 1, which can be found in oil palm mills abundantly. Proximate data of EFB consist of moisture $9.38 \%$, ash 5.38\%, volatile matter $68.47 \%$, and fixed carbon $16.77 \%$; then calorific value $4,469 \mathrm{cal} / \mathrm{g}$. Thereafter, ultimate data comprise of carbon $46.5 \%$, hydrogen $7.13 \%$, nitrogen $0.89 \%$, total sulphur $0.21 \%$ and oxygen $39.89 \%$ (all the data are in the air dry basis) [15]. Oil palm empty fruit bunches were knowing to contain a very high moisture content of around $60 \%-65 \%$, and contain potassium $(K)$ which reaches $2.4 \%$ [16]. In addition, the empty fruit bunches fibers have several disadvantages include high oil content, contains waxy layer on the fiber surface, have alkaline $\mathrm{pH}$ and of oil palm are known to contain chlorine $(\mathrm{Cl})$. The corrosion effect will increase with increasing $\mathrm{Cl}$ content, and elemental potassium can play a role in the formation of deposits in the super-heater that can interfere with the heat transfer process in the furnace $[16,17]$.

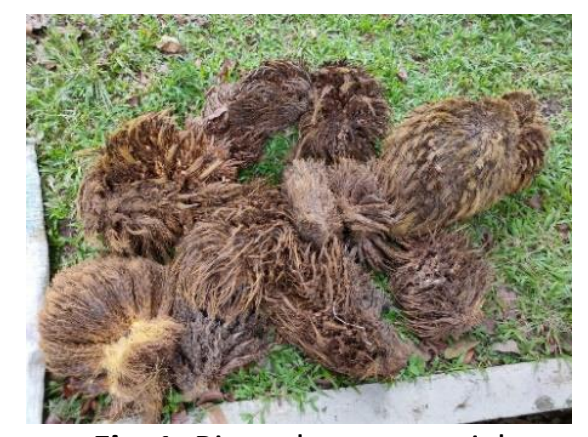

Fig. 1. Biocoal raw material

Indonesia is one of the largest palm oil producing countries in the world. In 2018, the area of oil palm plantations in Indonesia was recorded at 14,326,350 hectares, in 2019 the area of oil palm plantations reached 14,724,420 hectares and in 2020 it reached 14,996,010 hectares. From statistical data, the widest distribution of oil palm plantation area is on Sumatra Island and Kalimantan Island. This makes the two regions the largest producers of crude palm oil in Indonesia [18]. 


\subsubsection{Peat water}

The degree of acidity $(\mathrm{pH})$ of peat water is low, namely 3-5, because the main content of peat water is humic acid, fulvic acid and humin, which are coloring agents in peat water and the measurement of $\mathrm{pH}$ of peat water is show in Figure $2[19,20]$. Peat water is used to reduce potassium levels in empty oil palm fruit bunches because peat water is acidic (humic acid and fulvic acid) which has the nature of adsorption of minerals, so peat water can effectively dissolve potassium and its ability to dissolve is higher than ordinary water [21].

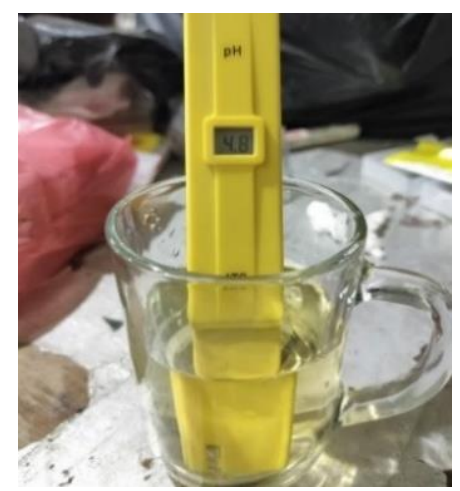

Fig. 2. Peat Water $\mathrm{pH}$ Level

\subsection{Experiment Set Up}

\subsubsection{Experiment preparation}

Washing of empty oil palm fruit bunches samples was carried out in Pambang Baru Village, Bantan District, Bengkalis Regency, Riau Province. The $\mathrm{pH}$ level (degree of acidity) of the peat water used for the washing process is 4.8 .

Dry oil palm empty bunches that have become fine fibers are first wash using peat water to reduce potassium (K) levels. Washing was carried out for 60 minutes with water flow rates of $2 \mathrm{lpm}$, $3 \mathrm{lpm}, 4 \mathrm{lpm}$ and $5 \mathrm{lpm}$. Samples of empty palm oil bunches to be wash were weighed as much as 100 grams per wash. After the washing process, the empty oil palm fruit bunches were dry again under the sun.

\subsubsection{Torrefaction method}

Torrefaction is a mild pyrolysis that usually the imposition temperature is around $200-300^{\circ} \mathrm{C}$. This process will remove the moisture in the biomass sample and alters the lignocellulosic composition. Torrefaction treatment on many species showed significant improvement of the biomass quality such as low volatile matters, high carbon content and importantly high calorific value [13]. The torrefaction product will be easier to reduce in size so that the energy consumption to reduce the size decreases. The increase in heating value obtained is directly proportional to the increase in temperature and torrefaction time. Meanwhile, the effect of increasing particle size actually decreases the heating value obtained [21]. The quality of the torrefaction product is largely determined by the characteristics of the biomass, temperature and duration of the torrefaction process. The longer of torrefaction process can cause the energy components to be lost so that the energy content will decrease [11].

The torrefaction process was carried out at the Energy Conversion Laboratory, Department of Mechanical Engineering, Faculty of Engineering, and University of Riau and the scematic of 
experiment set up as show in Figure 3. This torrefaction process uses a reactor made of stainless steel and a ceramic band heater to heat the sample.

The experiment procedure for oil palm empty fruit bunches in the torrefaction process were;

i. All of torrefaction test equipment were Install, and ensure that the components and measuring instruments are functioning properly.

ii. Dry palm empty bunches that have gone through the washing process using peat water are put into the reactor tube as much as 100 grams for each test.

iii. The reactor were Close tightly using a wrench.

iv. The heater is turned on, the heating level on the temperature controller is set to $300^{\circ} \mathrm{C}$.

v. After reaching the required process temperature, the sample was torrefaction for 30 minutes.

vi. When finished the heater is turned off.

vii. The reactor was allowed to cool to ambient temperature, after which samples were taken.

viii. The torrefaction sample was weighed again and stored in an airtight container.

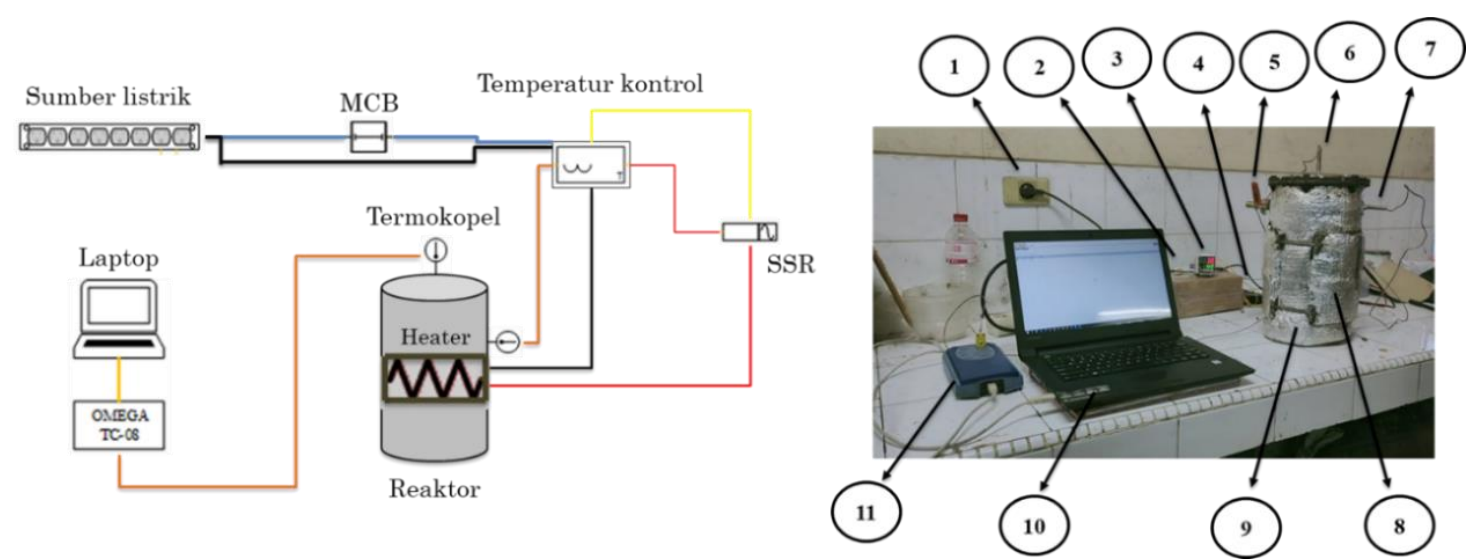

Fig. 3. Torrefaction Process Schematic; 1. Power source; 2. Miniatur circuit breaker (MCB); 3. Temperature controller; 4 . Solid state relay (SSR); 5 . Ball valve; 6 \& 7 Thermocouple $1 \& 2 ; 8$. Heater; 9. Reactor; 10. Laptop; 11. Data logger

\subsection{Data Collection}

\subsubsection{Heating value}

Heating value is one of the important parameters in fuel quality because heating value is the amount of energy released when a fuel is completely burn in a steady flow process. High heating value is the calorific value obtained experimentally using a bomb calorimeter as shown in Figure 4. Calorific value is the most important parameter of any biomass to be listed as potential energy crop. Then, the value continues to increase after the temperature was increased. This result is accordingly with the carbon content and volatile matters result. The value of carbon content and volatile matters is interrelated even though the relationship is complex. Biomass with low volatile matters, usually contain higher amount of carbon and will also has high calorific value [13]. 


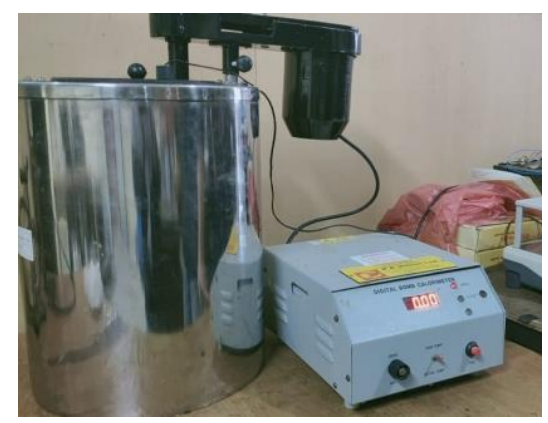

Fig. 4. Bomb Calorimeter

Furthermore, to calculate the heating value of the biocoal sample, it can be calculate using the following equation

$q=\frac{(\varepsilon \times \theta)-Q f u s e-Q i g n}{m f}$

where,

$\mathrm{q}=$ heating value $(\mathrm{kJ} / \mathrm{kg})$

$\varepsilon=$ value for bomb (11214.34 J)

$\theta=$ calorimeter temperature rise $\left({ }^{\circ} \mathrm{C}\right)$

Qfuse = Value for cotton yarn (1487.21 J)

Qign = Value for nichrome wire $(56.1 \mathrm{~J})$

$\mathrm{mf}=$ Mass of fuel sample (gr)

\subsubsection{Potassium and potassium oxide content}

The burning process of empty palm oil bunches will cause the potassium contained to change to form $\mathrm{K}_{2} \mathrm{O}$ compounds (potassium oxide) so that it can cause the risk of fouling and slagging. Slagging and fouling are phenomena of sticking and accumulating fused fuel ash on the heat exchanger tube or boiler wall. The impact can cause problems such as heat transfer, decreased boiler efficiency, pipe blockages, and pipe damage [14].

Potassium oxide $\left(\mathrm{K}_{2} \mathrm{O}\right)$ levels in biocoal samples were test by using XRF as shown in Figure 5 . XRF (X-Ray Fluorescence) is a method to be able to analyze the elemental composition in a sample quickly. The principle used is the determination of the elemental composition based on the interaction of $X$ rays with matter. Samples analyzed can be in the form of powder or lumps, weighing at least 5 grams.

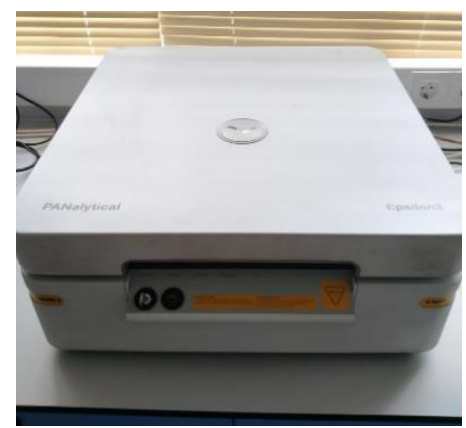

Fig. 5. X-Ray Fluorescence 


\section{Results and Discussion}

Biocoal samples from oil palm empty fruit bunches resulting from the washing process using peat water and the torrefaction process will be test for potassium oxide $\left(\mathrm{K}_{2} \mathrm{O}\right)$ content and heating value. Test of potassium oxide $\left(\mathrm{K}_{2} \mathrm{O}\right)$ content was conduct at the Chemistry Laboratory, Padang State University by using X-Ray Fluorescence (XRF) device. The heating value test was using a bomb calorimeter and it was conduct at the Energy Conversion Laboratory.

Table 2 shows the torrefaction process on empty oil palm fruit bunches without washing as a biocoal material can increasing the heating value of the sample. The heating value of oil palm empty fruit bunches was only $7333.40 \mathrm{~kJ} / \mathrm{kg}$ without torrefaction process and as shown in Table 2, the heating value of the sample increases with the increasing in the temperature of the torrefaction process. The increasing of heating value with the torrefaction process is due to the higher temperature of the torrefaction process causing the carbon content to increase and the water content and volatile matter content to decrease.

Table 2

Torrefaction Process Observation Data

\begin{tabular}{lllll}
\hline$\dot{V}(\mathrm{lpm})$ & Ttor $\left({ }^{\circ} \mathrm{C}\right)$ & $\mathrm{m} 1$ & $\mathrm{~m} 2$ & $\mathrm{q}(\mathrm{kJ} / \mathrm{kg})$ \\
\hline 0 & 0 & 0 & 0 & 7333.40 \\
0 & 200 & 100 & 76 & 16630.43 \\
0 & 250 & 100 & 60 & 19613.75 \\
0 & 300 & 100 & 43 & 25458.91 \\
\hline
\end{tabular}

Biocoal production by washing process using peat water and the torrefaction process on empty oil palm fruit bunches has proven to increasing the heating value. The highest heating value of biocoal was obtain $28,524.4 \mathrm{~kJ} / \mathrm{kg}$ in the washing process by flowing peat water of $5 \mathrm{lpm}$ and the torrefaction process at temperature of $300^{\circ} \mathrm{C}$ for 30 minutes. As shown in Figure 6 the heating value of biocoal also increases with the increasing the flow rate of water, thus it can be concluded that the washing process will remove the ash content in empty oil palm fruit bunches, resulting in a high heating value of biocoal, there are an increasing in heating value about $12 \%$.

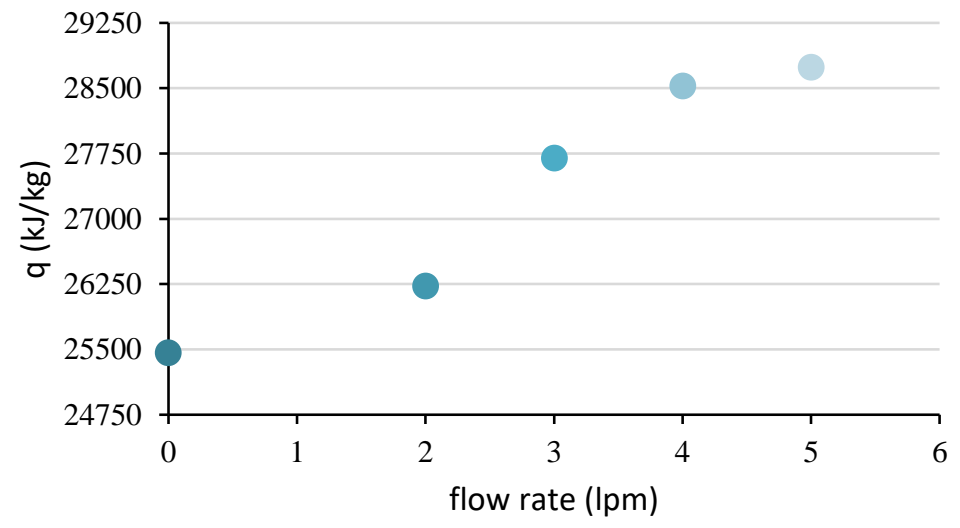

Fig. 6. Heating value with variant of flow rate

The result of this study was compared with other research and resulting the heating value of this research has higher than some previous research. Biocoal production from empty oil palm fruit bunches by torrefaction process at $275^{\circ} \mathrm{C}$ for 45 minutes resulted the heating value is $20697.13 \mathrm{~kJ} / \mathrm{kg}$ 
[22]. Biocoal production from palm shells by torrefaction process at $350^{\circ} \mathrm{C}$ for 20 minutes and by flowing of nitrogen at $300 \mathrm{ml} /$ minute resulted the heating value is $28,200 \mathrm{~kJ} / \mathrm{kg}$ [23].

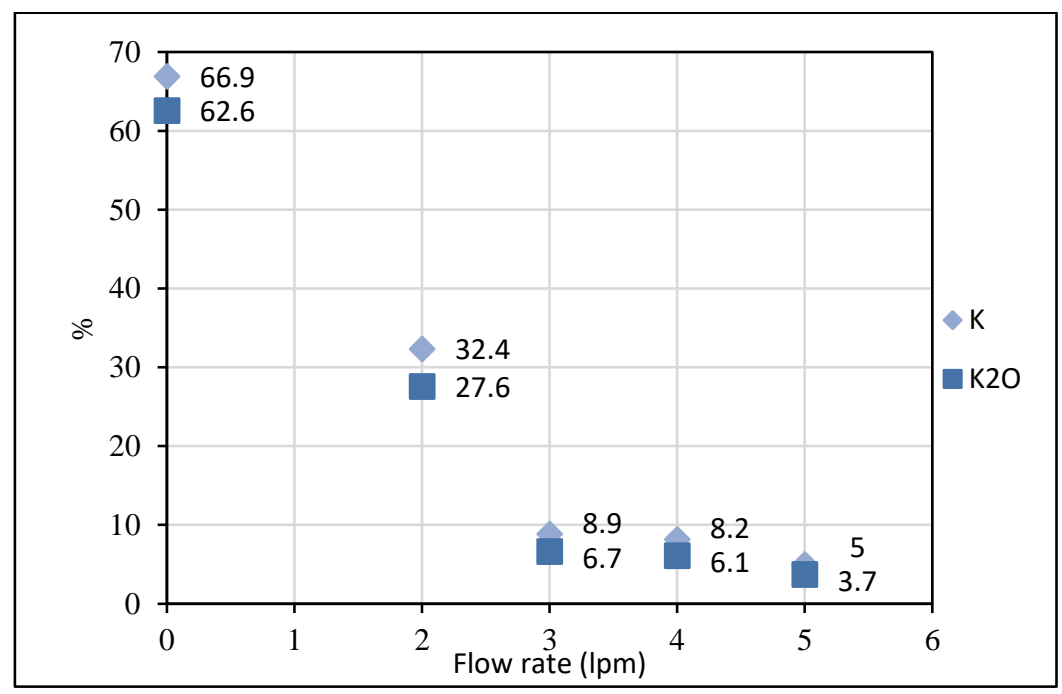

Fig. 7. Graph of Discharge vs Potassium and Potassium Oxide $\left(\mathrm{K}_{2} \mathrm{O}\right)$

Washing process on empty oil palm fruit bunches using peat water has proven to reduce potassium $(\mathrm{K})$ and potassium oxide $\left(\mathrm{K}_{2} \mathrm{O}\right)$ and it can be seen in Figure 7 . The unwashed initial sample has $66.9 \%$ potassium and $62.6 \%$ potassium dioxide contents. The content of potassium and potassium oxide $\left(\mathrm{K}_{2} \mathrm{O}\right)$ were decreases with increasing water flow and resulted the reducing of potassium content at $5 \mathrm{lpm}$ water flow with the remaining potassium and potassium oxide $\left(\mathrm{K}_{2} \mathrm{O}\right)$ content of 5 and $3.7 \%$ respectively. The decreasing of potassium $(\mathrm{K})$ content in empty oil palm fruit bunches was due to the ash content consisting of potassium and minerals dissolved and carried away by flowing water during the washing process.

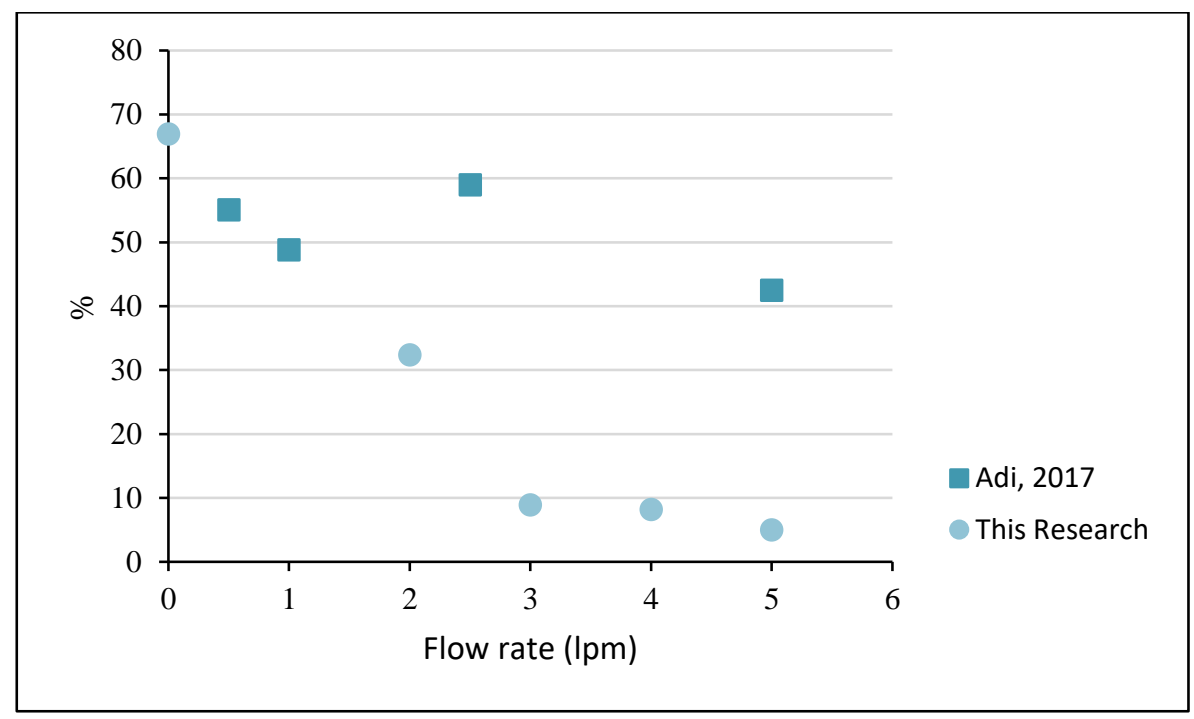

Fig. 8. Comparison of Potassium Content with previous research

The washing process with peat water on empty oil palm fruit bunches as a biocoal material has proven to reduce the potassium and potassium dioxide content in biocoal by decreasing up to $5 \%$ and $3.7 \%$, respectively. In previous research, where empty palm oil bunches were washed using only with ordinary water, the remaining potassium in the material only reached $42.5 \%$ with a water flow 
rate of $5 \mathrm{lpm}$ and the comparison between this research with the previous research can be saw in Figure 8 [14].

\section{Conclusion}

This research has been carried out on the production of biocoal from empty oil palm fruit bunches, which were previously washed using peat water to reduce potassium content by varying the water flow rate by $2 \mathrm{lpm}, 3 \mathrm{lpm}, 4 \mathrm{lpm}$ and $5 \mathrm{lpm}$. This research resulted the highest heating value of biocoal is $28742.17 \mathrm{~kJ} / \mathrm{kg}$ with $5 \mathrm{lpm}$ flow peat water in washing process for 60 minute and at $300^{\circ} \mathrm{C}$ in torrefaction process for 30 minute.

In this study, it was also found that the washing process with peat water on empty oil palm fruit bunches as a biocoal material has proven to reduce the potassium and potassium dioxide content in biocoal with a decrease of up to $5 \%$ and $3.7 \%$, respectively.

\section{Acknowledgement}

The authors gratefully acknowledge the generous financial support given by the University of Riau under Hibah Penelitian Universitas Riau-No. 661/UN.19.5.1.3/PT.01.03/2021 with a title "Pemanfaatan Air Gambut untuk Penurunan Kadar Kalium pada Produksi Biocoal dari Limbah Tandan Kosong Sawit dengan Metode Torefaksi".

\section{Reference}

[1] Humas EBTKE. "Menteri Arifin: Transisi Energi Mutlak Diperlukan." Direktorat Jenderal Energi Baru Terbarukan dan Konservasi Energi (EBTKE). October 22, 2020.

https://ebtke.esdm.go.id/post/2020/10/22/2667/menteri.arifin.transisi.energi.mutlak.diperlukan

[2] Adistia, Nurul Amandha, Rizky Aditya Nurdiansyah, Juno Fariko, Vincent Vincent, and Joni Welman Simatupang. "Potensi Energi Panas Bumi, Angin, Dan Biomassa Menjadi Energi Listrik di Indonesia." TESLA: Jurnal Teknik Elektro 22, no. 2 (2020): 105-116. https://doi.org/10.24912/tesla.v22i2.9107

[3] Presiden Republik Indonesia. "Undang-Undang Nomor 30 Tahun 2007 Tentang Energi." Republik Indonesia. August 9, 2016. https://www.ojk.go.id/sustainable-finance/id/peraturan/undang-undang/Pages/Undang-UndangRepublik-Indonesia-Nomor-30-Tahun-2007-Tentang-Energi.aspx

[4] Nasruddin, Awaludin Martin, Muhammad Idrus Alhamid, and Daniel Tampubolon. "Adsorption Isotherms of Hydrogen on Granular Activated Carbon Derived From Coal and Derived From Coconut Shell." Heat Transfer Engineering 38, no. 4 (2017): 403-408. https://doi.org/10.1080/01457632.2016.1194703

[5] Presiden Republik Indonesia. "Peraturan Presiden Republik Indonesia Nomor 22 Tahun 2017 tentang Rencana Umum Energi Nasional." Republik Indonesia. March 2, 2017.

https://jdih.esdm.go.id/index.php/web/result/1648/detail

[6] Humas EBTKE. "Terapkan Metode Co-Firing Di PLTU Ini Potensi Biomassa Untuk Subtitusi Batubara." Direktorat Jenderal Energi Baru Terbarukan dan Konservasi Energi (EBTKE). February $28,2020$. https://ebtke.esdm.go.id/post/2020/02/28/2490/terapkan.metode.co-

firing.di.pltu.ini.potensi.biomassa.untuk.subtitusi.batubara

[7] Parinduri, Luthfi, and Taufik Parinduri. "Konversi biomassa sebagai sumber energi terbarukan." JET (Journal of Electrical Technology) 5, no. 2 (2020): 88-92.

[8] BPS. "Produksi Perkebunan Kelapa Sawit Indonesia Terus Naik dalam Lima Tahun Terakhir." Badan Pusat Statistik. November 30, 2020. https://databoks.katadata.co.id/datapublish/2020/11/30/produksi-perkebunan-kelapasawit-indonesia-terus-naik-dalam-lima-tahun-terakhir

[9] Ristianingsih, Yuli, Ayuning Ulfa, and Rachmi Syafitri KS. "Pengaruh Suhu dan Konsentrasi Perekat Terhadap Karakteristik Briket Bioarang Berbahan Baku Tandan Kosong Kelapa Sawit dengan Proses Pirolisis." Konversi 4, no. 2 (2015): 45-51. https://doi.org/10.20527/k.v4i2.266

[10] Surono, Untoro Budi, Harwin Saptoadi, and Tri Agung Rohmat. "The Effects of Torrefaction on Lignocellulose Composition and Moisture Absorption Ability of Cocoa Pod Husk." Journal of Advanced Research in Fluid Mechanics and Thermal Sciences 71, no. 1 (2020): 83-91. https://doi.org/10.37934/arfmts.71.1.8391 
[11] Irawan, Anton, Tubagus Riadz, and Nurmalisa Nurmalisa. "Proses Torefaksi Tandan Kosong Kelapa Sawit Untuk Kandungan Hemiselulosa Dan Uji Kemampuan Penyerapan Air." Reaktor 15, no. 3: $190-194$. https://doi.org/10.14710/reaktor.15.3.190-194

[12] Fuad, Muhammad Ariff Hanaffi Mohd, Mohamad Muslihuddin Razali, Zaitul Nadiah Mohamad Izal, Hasan Mohd Faizal, Norhayati Ahmad, Mohd Rosdzimin Abdul Rahman, and Md Mizanur Rahman. "Torrefaction of Briquettes Made of Palm Kernel Shell with Mixture of Starch and Water as Binder." Journal of Advanced Research in Fluid Mechanics and Thermal Sciences 70, no. 2 (2020): 21-36. https://doi.org/10.37934/arfmts.70.2.2136

[13] Rahman, Adli Azimi Abdul, Ras Izzati Ismail, and Abdul Razak Shaari. "Torrefaction Temperature and Holding Time Effect on Khaya Senegalensis Biomass." Journal of Advanced Research in Fluid Mechanics and Thermal Sciences 81, no. 1 (2021): 150-157. https://doi.org/10.37934/arfmts.81.1.150157

[14] Prismantoko, Adi, Yayan Heryana, Yoga Peryoga, and Agung Wijono. "Reduksi Kandungan Kalium Tandan Kosong Kelapa Sawit Dengan Pencucian Metoda Aliran Air." Prosiding Semnastek (2017).

[15] Mahidin, Mahidin, Erdiwansyah Erdiwansyah, H. Husin, Hisbullah Hisbullah, A. P. Hayati, M. Zhafran, M. A. Sidiq et al. "Utilization of Oil Palm Biomass as a Renewable and Sustainable Energy Source in Aceh Province." Journal of Advanced Research in Fluid Mechanics and Thermal Sciences 67, no. 2 (2020): 97-108.

[16] Wijono, Agung. "PLTU biomasa tandan kosong kelapa sawit studi kelayakan dan dampak lingkungan." Balai Rekayasa Disain Dan Sistem Teknologi (2014).

[17] Ibrahim, Zawawi, Mansur Ahmad, Astimar Abdul Aziz, Ridzuan Ramli, Noorshamsiana Abdul Wahab, Aisyah Humaira Alias, Syaiful Osman, and Ewe Lay Sheng. "Oil Palm Empty Fruit Bunches (EFB): Influence of Alkali and Acid Treatment on the Mechanical Properties of Medium Density Fibreboard (MDF)." Journal of Advanced Research in Fluid Mechanics and Thermal Sciences 79, no. 1 (2020): 44-53. https://doi.org/10.37934/arfmts.79.1.4453

[18] Gartina, Dhani, and R. Lucky Lukmana Sukriya. "Statistik Perekebunan Indonesia 2018-2020: Kelapa Sawit." Direktorat Jenderal Perkebunan (2019).

[19] Menteri Kesehatan Republik Indonesia. "Peraturan Menteri Kesehatan No.492/MENKES/PER/IV/2010 Tentang Persyaratan Kualitas Air Minum dan Peraturan Pemerintah No. 82 Tahun 2001 Tentang Pengelolaan Kualitas Air Dan Pengendalian Pencemaran Air." Republik Indonesia (2010).

[20] Presiden Republik Indonesia. "Peraturan Pemerintah No. 82 Tahun 2001 Tentang Pengelolaan Kualitas Air Dan Pengendalian Pencemaran Air." Republik Indonesia (2001).

[21] Shaker, Ali M., Zanaty R. Komy, Said EM Heggy, and Mohamed EA El-Sayed. "Kinetic study for adsorption humic acid on soil minerals." The Journal of Physical Chemistry A 116, no. 45 (2012): 10889-10896. https://doi.org/10.1021/jp3078826

[22] Fernando, A. Q., and Z. Helwani. "Torefaksi Tandan Kosong Sawit: Pengaruh Kondisi Proses terhadap Nilai Kalor Produk Torefaksi." PhD diss., Riau University, 2016.

[23] Asadullah, Mohammad, Ag Mohammad Adi, Nurul Suhada, Nur Hanina Malek, Muhammad Ilmam Saringat, and Amin Azdarpour. "Optimization of palm kernel shell torrefaction to produce energy densified bio-coal." Energy Conversion and Management 88 (2014): 1086-1093. https://doi.org/10.1016/j.enconman.2014.04.071 